\title{
The Acute Effect of Insulin on Heart Rate, Blood Pressure, Plasma Noradrenaline and Urinary Albumin Excretion
}

\author{
The Role of Changes in Blood Glucose \\ C. E. Mogensen, N. J. Christensen, and H. J. G. Gundersen \\ Medical Department I, Århus Amtssygehus, Århus; Department of Internal Medicine and Endocrinology, Herlev Hospital, Herlev; \\ 2nd University Clinic of Internal Medicine, Kommunehospital, Århus; and Institute of Experimental Clinical Research, \\ University of Arhus, Århus, Denmark
}

\begin{abstract}
Summary. The effect of intravenous insulin $(7-8 \mathrm{U}$ as a bolus injection) on renal haemodynamics and urinary excretion of albumin and beta-2-microglobulin was examined in five recent onset juvenile diabetics. Blood glucose concentration was maintained after insulin at unchanged or slightly increased levels by continuous intravenous glucose infusion $(50 \mathrm{~g} / 100$ $\mathrm{ml}, 1.2 \mathrm{ml} / \mathrm{min})$. Mean arterial blood pressure increased slightly but significantly from $94 \pm$ $8 \mathrm{mmHg}$ to $99 \pm 10$ (mean $\pm \mathrm{SD}$ ) after insulin. The rise in heart rate (16 versus 29 beats $/ \mathrm{min}$ ) and in plasma noradrenaline (from 0.16 to $0.32 \mathrm{ng} / \mathrm{ml}$ versus 0.20 to $0.49 \mathrm{ng} / \mathrm{ml}$ ) was significantly greater in the tilted position after insulin. There was no decrease in glomerular filtration rate or renal plasma flow after insulin, in contrast to the findings after intravenous injection of insulin without maintenance of plasma glucose. Urinary albumin excretion was approximately doubled after insulin, from 6.8 to $12.5 \mu \mathrm{g} / \mathrm{min}$. Beta-2-microglobulin excretion decreased but this difference was not significant. - It is concluded that the rise in heart rate and plasma noradrenaline, and the increase in urinary albumin excretion, after insulin, are unrelated to changes in blood glucose concentration. It is suggested that increased albumin excretion after insulin is due to a direct effect of insulin on glomerular endothelial or epithelial cells.
\end{abstract}

Key words: Arterial blood pressure, blood glucose, cardiovascular system, diabetes mellitus, glomerular filtration rate, heart rate, insulin, noradrenaline, renal plasma flow, urinary albumin excretion.

It is now known that insulin, apart from its influence on metabolism and on ion fluxes, has a marked acute effect on sympathetic nervous system activity, and on the cardiovascular system [1-5]. Despite an increase in plasma noradrenaline and heart rate after intravenous insulin, arterial blood pressure does not increase, and may even fall, in patients with autonomic neuropathy $[6,7,8,9]$. Furthermore, insulin induced hypovolaemia and increased urinary excretion of albumin, and increased the number of micropinocytotic vesicles in muscle capillary endothelial cells $[3,5,10,11]$. Recent studies in rabbits have shown that the rise in heart rate after insulin is not mediated by the autonomic nervous system [12]. The role of glucose in these changes has not been established and the aim of the present study was to examine whether the acute cardiovascular effects of insulin are modified when the blood glucose concentration is kept constant after intravenous insulin.

\section{Patients}

Five male insulin-dependent diabetic out-patients were studied. They were otherwise healthy and received no other medication. Their mean age was 29 years and the duration of diabetes averaged 8 years. None of the patients has clinical signs of peripheral neuropathy. Pertinent clinical data are shown in Table 1 . They were all treated with twice daily insulin and had their last dose of insulin $24 \mathrm{~h}$ before the investigation. Informed consent was obtained from all subjects, all of whom had been previously studied [5].

\section{Procedure}

The patients were studied in the morning after an overnight fast. They were studied lying down, standing up only to pass urine. They drank $20 \mathrm{ml}$ of water every $20 \mathrm{~min}$ throughout the study, starting $1 \mathrm{~h}$ beforehand. Following a resting period of $1^{1 / 2} \mathrm{~h}$ glomerular filtration rate (GFR), renal plasma flow (RPF), urinary albumin and beta-2-microglobulin excretion were measured in three 45 min periods before, and three 45 min periods after, insulin. Insulin 7-8 U (Actrapid, Novo) was given IV as a bolus injection. At the same time an infusion of $50 \mathrm{~g} / 100 \mathrm{ml}$ glucose was 
Table 1. Pertinent clinical data in the 5 male insulin dependent diabetics studied

\begin{tabular}{llcll}
\hline $\begin{array}{l}\text { Patient } \\
\text { (no.) }\end{array}$ & $\begin{array}{l}\text { Age } \\
\text { (years) }\end{array}$ & $\begin{array}{l}\text { \% of ideal } \\
\text { body weight }\end{array}$ & $\begin{array}{l}\text { Diabetes } \\
\text { duration } \\
\text { (years) }\end{array}$ & $\begin{array}{l}\text { Usual insulin } \\
\text { dose } \\
\text { (XU/24 h) }\end{array}$ \\
\hline 1 & 36 & 97 & 7 & 64 \\
2 & 23 & 92 & 10 & 56 \\
3 & 29 & 109 & 6 & 48 \\
4 & 29 & 118 & 8 & 60 \\
5 & 27 & 97 & 10 & 72 \\
\hline
\end{tabular}

Patient 4 had mild background retinopathy

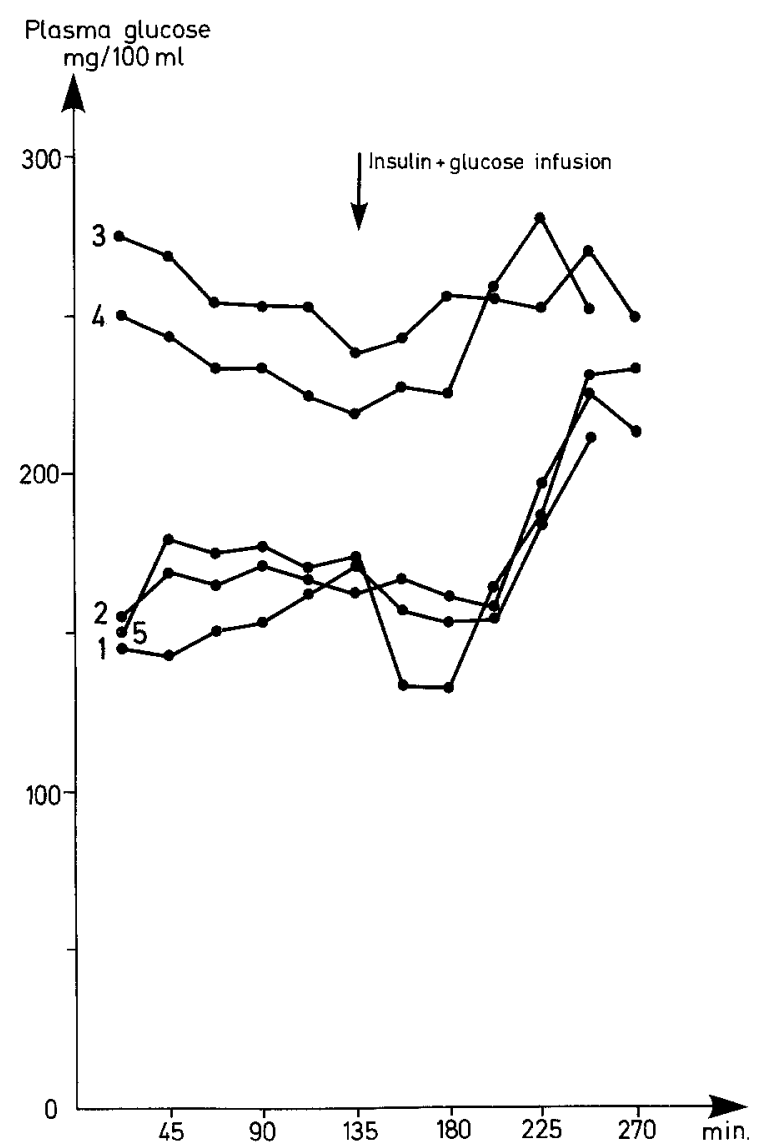

Fig. 1. Individual plasma glucose concentrations $(\mathrm{mg} / 100 \mathrm{ml})$ in five diabetics examined for three $45 \mathrm{~min}$ periods before and three 45 min periods after intravenous injection of insulin ( 7 or $8 \mathrm{U}$ ) with a continuous IV glucose infusion $(50 \mathrm{~g} / 100 \mathrm{ml}, 1.2 \mathrm{ml} / \mathrm{min})$. Results were obtained at 22 and $45 \mathrm{~min}$ in each period

started at a rate of about $1.2 \mathrm{ml} / \mathrm{min}$, and ran throughout the subsequent 3 periods. Before and after insulin the subjects were tilted $60^{\circ}$ feet-down for $7 \mathrm{~min}$ in the beginning of the first and the second clearance period respectively.

Plasma noradrenaline and adrenaline were measured at the end of each $45 \mathrm{~min}$ clearance period before insulin, at $45 \mathrm{~min}$ after insulin and at 6 min during tilting both before and after insulin. Plasma glucose concentration was measured at 22 and $45 \mathrm{~min}$ in each $45 \mathrm{~min}$ period.
Heart rate and arterial blood pressure were measured twice during each clearance period, three times during the first period after insulin, and at $2 \mathrm{~min}$ intervals during tilting.

\section{Methods}

GFR and RPF were measured by constant infusion techniques using ${ }^{125}$ I-iothalamate for GFR and ${ }^{131}$ I-hippuran for RPF [13]. A total volume of $50 \mathrm{ml}$ was infused during an experiment. The urinary concentration of albumin and beta-2-microglobulin (Phadebas beta ${ }_{2}$-micro Test) was measured by radioimmunoassay $[14,15]$. Plasma noradrenaline and adrenaline were measured by double-isotope derivative assay $[16,17]$. Arterial blood pressure was measured indirectly by a sphygmomanometer. Mean arterial blood pressure was calculated as diastolic blood pressure plus one third of the pulse amplitude. Plasma glucose was determined by an ortho-toluidine method. The concentrations of sodium, potassium, phosphate, calcium, and creatinine were measured by standard methods (Technicon Autoanalyzer SMA-10) in serum samples taken in the middle of each period as well as in urine samples. The Wilcoxon rank test and Student's t-test for paired samples were used for testing statistical significance [18].

\section{Results}

Mean glucose concentration before insulin averaged $196 \mathrm{mg} / 100 \mathrm{ml}$ (range 154 to 257 ). Figure 1 shows changes in blood glucose concentration in each subject after intravenous insulin injection with intravenous glucose infusion. One subject showed a small decrease in blood glucose concentration in the first period after the injection of insulin. Blood glucose concentration increased significantly $(2 \mathrm{p}=0.038)$ above basal at the end of the second and during the third period after insulin.

There were no significant changes in glomerular filtration rate and in renal plasma flow after insulin (Table 2). Urine flow, however, decreased significantly $(2 \mathrm{p}=0.022)$ after insulin and averaged in the three post-insulin periods only $55 \%$ of pre-insulin values (Table 2). Mean albumin excretion averaged $6.8 \mu \mathrm{g} / \mathrm{min}$ before insulin and increased to $12.5 \mu \mathrm{g} /$ min after insulin $(194 \%$ of basal value, $2 \mathrm{p}=0.022$, Table 3). There was a close correlation between basal albumin excretion and the maximal rise in albumin excretion after insulin $(r=0.98,2 \mathrm{p}=0.0031)$. Mean beta-2-microglobulin excretion decreased in 4 of the 5 diabetics after insulin but the difference was not significant (Table 3).

As expected, plasma noradrenaline and adrenaline increased during tilting. Plasma adrenaline did not change after insulin while plasma noradrenaline was significantly greater in the tilted position after insulin $(149 \%$ of control value, $2 \mathrm{p}=0.019$, Table 4$)$.

Mean arterial blood pressure increased slightly in the second period after insulin (from $94 \pm 8 \mathrm{mmHg}$ to $99 \pm 10$ (mean $\pm \mathrm{SD}), 2 \mathrm{p}=0.047)$. Systolic and 
Table 2. Mean glomerular filtration rate, renal plasma flow and urinary flow in five diabetics examined in three 45 min clearance periods before and three 45 min clearance periods after intravenous injection of insulin with glucose infusion. Results given as mean \pm SD

\begin{tabular}{|c|c|c|c|c|c|}
\hline \multicolumn{3}{|c|}{ Pre-insulin periods (min) } & \multicolumn{3}{|c|}{ Post-insulin periods (min) } \\
\hline $0-45$ & $45-90$ & $90-135$ & $0-45$ & $45-90$ & $90-135$ \\
\hline \multicolumn{6}{|c|}{ Glomerular filtration rate $(\mathrm{ml} / \mathrm{min})$} \\
\hline $130 \pm 24$ & $146 \pm 14$ & $136 \pm 9$ & $135 \pm 16$ & $132 \pm 18$ & $124 \pm 29$ \\
\hline \multicolumn{6}{|c|}{ Renal plasma flow (ml/min) } \\
\hline $549 \pm 97$ & $624 \pm 119$ & $559 \pm 45$ & $540 \pm 48$ & $545 \pm 74$ & $530 \pm 100$ \\
\hline \multicolumn{6}{|c|}{ Urine flow (ml/min) } \\
\hline $2.0 \pm 0.7$ & $2.1 \pm 1.0$ & $2.8 \pm 1.5$ & $1.4 \pm 0.4$ & $1.0 \pm 0.5$ & $1.4 \pm \quad 0.9$ \\
\hline
\end{tabular}

Table 3. Urinary excretion of albumin $(\mu \mathrm{g} / \mathrm{min})$ and of $\beta-2-\operatorname{microglobulin}(\mathrm{ng} / \mathrm{min})$ before and after insulin injection with glucose infusion in five juvenile diabetics

\begin{tabular}{|c|c|c|c|c|c|c|}
\hline \multirow[t]{2}{*}{ Patient } & \multicolumn{3}{|c|}{ Pre-insulin periods (min) } & \multicolumn{3}{|c|}{ Post-insulin periods (min) } \\
\hline & $0-45$ & $45-90$ & $90-135$ & $0-45$ & $45-90$ & $90-135$ \\
\hline 1 Albumin & 4.1 & 3.7 & 2.9 & 3.2 & 4.3 & 5.3 \\
\hline$\beta$-2-microglobulin & 140 & 161 & 116 & 62 & 48 & 75 \\
\hline 2 Albumin & 7.7 & 4.5 & 8.4 & 3.3 & 20.9 & 18.6 \\
\hline$\beta$-2-microglobulin & 115 & 110 & 163 & 74 & 24 & 74 \\
\hline 3 Albumin & 3.2 & 2.3 & 2.1 & 4.2 & 7.8 & 4.6 \\
\hline$\beta$-2-microglobulin & 126 & 122 & 157 & 151 & 86 & 126 \\
\hline 4 Albumin & 22.2 & 13.2 & 12.3 & 8.6 & 56.9 & 8.7 \\
\hline$\beta$-2-microglobulin & 73 & 68 & 58 & 64 & 87 & 77 \\
\hline 5 Albumin & 5.6 & 4.5 & 5.1 & 18.6 & 12.9 & 9.5 \\
\hline$\beta$-2-microglobulin & 56 & 38 & 43 & 38 & 46 & 16 \\
\hline
\end{tabular}

Table 4. Plasma noradrenaline $(\mathrm{ng} / \mathrm{ml})$ and adrenaline $(\mathrm{ng} / \mathrm{ml})$ in the supine position and at 6 min intervals during tilting. Results were obtained in five diabetics studied for three $45 \mathrm{~min}$ periods before and in the first period after intravenous injection of insulin with glucose infusion

\begin{tabular}{|c|c|c|c|c|c|c|}
\hline \multirow[t]{2}{*}{ Nos. } & \multicolumn{4}{|c|}{ Pre-insulin periods } & \multicolumn{2}{|c|}{ Post-insulin periods } \\
\hline & $\begin{array}{l}\text { Supine } \\
\text { at } 45 \mathrm{~min}\end{array}$ & $\begin{array}{l}\text { Tilted for } \\
6 \mathrm{~min}\end{array}$ & $\begin{array}{l}\text { Supine } \\
\text { at } 90 \mathrm{~min}\end{array}$ & $\begin{array}{l}\text { Supine } \\
\text { at } 135 \mathrm{~min}\end{array}$ & $\begin{array}{l}\text { Supine } \\
\text { at } 45 \mathrm{~min}\end{array}$ & $\begin{array}{l}\text { Tilted for } \\
6 \mathrm{~min}\end{array}$ \\
\hline \multicolumn{7}{|c|}{ Noradrenaline $\mathrm{ng} / \mathrm{ml}$} \\
\hline 1 & 0.25 & 0.58 & 0.17 & 0.16 & 0.29 & 0.91 \\
\hline 2 & 0.13 & 0.19 & 0.11 & 0.10 & 0.11 & 0.23 \\
\hline 3 & 0.07 & 0.19 & 0.09 & 0.10 & 0.17 & 0.28 \\
\hline 4 & 0.17 & 0.31 & 0.18 & 0.19 & 0.30 & 0.65 \\
\hline 5 & 0.17 & 0.35 & 0.13 & 0.12 & 0.11 & 0.38 \\
\hline Mean & 0.16 & 0.32 & 0.14 & 0.13 & 0.20 & 0.49 \\
\hline \multicolumn{7}{|c|}{ Adrenaline $\mathrm{ng} / \mathrm{ml}$} \\
\hline 1 & 0.03 & 0.04 & 0.03 & 0.01 & 0.01 & 0.04 \\
\hline 2 & 0.03 & 0.05 & 0.02 & 0.02 & 0.02 & 0.07 \\
\hline 3 & 0.03 & 0.06 & 0.03 & 0.03 & 0.03 & 0.11 \\
\hline 4 & 0.02 & 0.04 & 0.03 & 0.01 & 0.03 & 0.04 \\
\hline 5 & 0.02 & 0.03 & 0.03 & 0.03 & 0.03 & 0.05 \\
\hline Mean & 0.03 & 0.04 & 0.03 & 0.02 & 0.02 & 0.06 \\
\hline
\end{tabular}


diastolic blood pressure increased by approximately the same extent, that is a small rise in diastolic blood pressure contributed most to the rise in mean blood pressure. There was no difference in arterial blood pressure at 6 min during tilting before or after insulin. Heart rate was slightly higher in the supine position in the second period after insulin $(7 \%$ increase, $2 \mathrm{p}=0.038$ ). At $6 \mathrm{~min}$ during tilting heart rate had increased 16 beats/min before insulin and 29 beats/ $\min$ after insulin. This difference is significant $(2 \mathrm{p}=$ 0.0085 ).

Renal excretion of several electrolytes decreased after insulin as previously described [5], whereas the urinary excretion rate of calcium increased from 135 to $199 \mu \mathrm{g} / \mathrm{min}, 2 \mathrm{p}=0.0078$. Despite the unchanged GFR a small decrease in the excretion rate of creatinine from 1.33 to $1.27 \mathrm{mg} / \mathrm{min}$ was found $(2 \mathrm{p}$ $=0.0094$ ).

\section{Discussion}

The acute cardiovascular effects of insulin described here were not due to hypoglycaemia $[3,5]$. It has been noticed that the increase in heart rate after insulin $[4,12]$ begins a few minutes after the insulin injection suggesting that this effect of insulin is not due to the fall in blood glucose concentration. The present study demonstrates that the rise in heart rate and plasma noradrenaline after insulin, as well as the increased urinary excretion of albumin were present in diabetics in whom blood glucose was maintained at unchanged or slightly increased levels by a glucose infusion. These effects of insulin were therefore unrelated to changes in blood glucose concentration. It should be noted that a rather large dose of insulin was given as a bolus intravenously, a method of administration not strictly comparable to physiological conditions.

The magnitude of the increase in albumin excretion after insulin in the present study was very similar to that in a previously reported study in which blood glucose was allowed to decline after insulin [5]. In another study in which no glucose infusion was given [3] the rise in heart rate and in plasma noradrenaline in the tilted position after insulin were 16 beats/min and $59 \%$ greater than control values, as compared to the 13 beats $/ \mathrm{min}$ and $49 \%$ observed in the present study. Changes in heart rate and in plasma noradrenaline concentration in the supine position were somewhat lower in the present study than observed previously $[3,5]$.

Urinary excretion of beta-2-microglobulin decreased after insulin in 4 of the 5 diabetics examined. Although this change did not reach statistical signifi- cance this is most likely explained by the relatively small number of patients examined. Glomerular filtration rate and renal plasma flow did not change after insulin plus glucose infusion in contrast to the relatively marked changes in these two indices observed previously after injection of insulin alone [5]. This finding indicates that the increase in albumin excretion after insulin is not simply due to a decrease in renal blood flow and in glomerular filtration rate. The increased urinary albumin excretion after insulin is most likely due to increased transglomerular passage of albumin. The earlier demonstrated decrease [5] in beta-2-microglobulin excretion after insulin suggests that also tubular reabsorption of proteins is increased.

The effect of insulin on urinary albumin excretion may be due to a direct effect of insulin on glomerular permeability or mediated via the autonomic nervous system. It is of interest in this context that insulin receptors in glomeruli have recently been demonstrated (K. Kurokawa, Los Angeles, personal communication). Insulin has been shown to increase the number of micropinocytotic vesicles in muscle capillary endothelial cells in rats [10]. This finding may suggest that effects of insulin on albumin excretion may be due to a direct effect of insulin on glomerular capillary endothelial or epithelial cells. The mechanism is unknown but may involve an increase in cytoplasmatic calcium concentration and contractile processes.

The mechanism of the rise in plasma noradrenaline after insulin has not been established. The increased noradrenaline secretion is unlikely to be derived from adrenal medulla because plasma adrenaline did not increase. The afferent signal for the increased noradrenaline secretion is not known but hypovolaemia is likely to play a role $[3,19]$.

Acknowledgement. This study was supported by grants from The Danish Medical Research Council and The Danish Heart Foundation.

The authors gratefully acknowledge the secretarial assistance of Mrs. R. Riis and the technical assistance of Mrs. Merete Møller and Mrs. Elin Bang.

\section{References}

1. Christensen NJ (1974) Plasma norepinephrine and epinephrine in untreated diabetics, during fasting and after insulin administration. Diabetes 23: 1-8

2. Christensen NJ, Alberti KGMM, Brandsborg O (1975) Plasma catecholamines and blood substrate concentrations: Studies in insulin induced hypoglycaemia and after adrenaline infusions. Eur J Clin Invest 5: 415-423

3. Gundersen HJG, Christensen NJ (1977) Intravenous insulin causing loss of intravascular water and albumin and increased adrenergic nervous activity in diabetics. Diabetes 26: 551-557 
4. Page MMcB, Smith RBW, Watkins PJ (1976) Cardiovascular effects of insulin. Br Med J I: 430-432

5. Mogensen CE, Christensen NJ, Gundersen HJG (1978) The acute effect of insulin on renal hemodynamics and protein excretion in diabetics. Diabetologia 15: 153-157

6. French EB, Kilpatrick R (1955) The role of adrenaline in hypoglycaemic reactions in man. Clin Sci Mol Med 14: 639-651

7. Miles DW, Hayter C J (1968) The effect of intravenous insulin on the circulatory responses to tilting in normal and diabetic subjects with special reference to baroceptor reflex block and atypical hypoglycaemic reactions. Clin Sci Mol Med 34: 419-430

8. Page MMcB, Watkins PJ (1976) Provocation of postural hypotension in diabetic autonomic neuropathy. Diabetes 25 : $90-95$

9. Mathias CJ, Frankel HL, Turner RC, Christensen NJ (in press) Physiological responses to insulin hypoglycemia in spinal man.

10. Østerby R, Gundersen HJG, Christensen NJ (1978) The acute effect of insulin on capillary endothelial cells. Diabetes 27: 745-749

11. MacKay JD, Hayakawa H, Watkins PJ (1978) Cardiovascular effects of insulin: Plasma volume changes in diabetics. Diabetologia 15: 453-457

12. Jacobsen F, Christensen NJ (1979) Stimulation of heart rate by insulin: Uninfluenced by beta-adrenergic receptor blockade in rabbits. Scand J Clin Lab Invest 39: 253-256
13. Mogensen CE (1971) Glomerular filtration rate and renal plasma flow in short-term and long-term juvenile diabetes mellitus. Scand J Clin Lab Invest 28: 91-100

14. Miles DW, Mogensen CE, Gundersen HJG (1970) Radioimmunoassay for urinary albumin using a single antibody. Scand J Clin Lab Invest 26: 5-11

15. Evrin PE, Peterson P A, Wide L, Berggård J (1971) Radioimmunoassay of beta-2-microglobulin in human biological fluids. Scand J Clin Lab Invest 28: 439-444

16. Engelman K, Portnoy B (1970) A sensitive double-isotope derivative assay for norepinephrine and epinephrine. Circ Res 26: 53-57

17. Christensen NJ (1973) Plasma noradrenaline and adrenaline in patients with thyrotoxicosis and myxoedema. Clin Sci Mol Med 45: 163-171

18. Documenta Geigy (1962) Scientific tables, Sixth ed. CibaGeigy, Basel

19. Christensen NJ (1979) Catecholamines and diabetes mellitus. Diabetologia 16: 211-24

Received: March 5, 1979, and in revised form: December 10, 1979

Dr. C. E. Mogensen

Medicinsk afdeling I

Ãrhus Amtssygehus

DK-8000 Århus C, Denmark 